\title{
Absence of Mutagenic Effect of Mikania glomerata Hydroalcoholic Extract on Adult Wistar Rats in vivo
}

\author{
Rita de Cássia da Silveira e Sá ${ }^{*}$, Magda Narciso Leite ${ }^{2}$, Vera Maria Peters ${ }^{3}$, Martha de \\ Oliveira Guerra ${ }^{4}$ and Reinaldo Nóbrega de Almeida ${ }^{5}$ \\ ${ }^{1}$ Departamento de Biologia. ${ }^{3,4}$ Centro de Biologia da Reprodução; ${ }^{2}$ Faculdade de Farmácia e Bioquímica; \\ Universidade Federal de Juiz de Fora; Campus Universitário; 36036-330; Juiz de Fora - MG - Brasil. ${ }^{5}$ Laboratório \\ de Tecnologia Farmacêutica; Universidade Federal da Paraíba; João Pessoa - PB - Brasil
}

\begin{abstract}
This work makes an assessment of the dominant lethality of Mikania glomerata in male Wistar rats. Adult male received $1 \mathrm{~mL}$ of $M$. glomerata hydroalcoholic extract at a dose level of $3.3 \mathrm{~g} / \mathrm{kg}$ body weight for 52 days and were mated with untreated females for seven weeks (group 1) or one week prior to the beginning of treatment and on the week following the end of treatment (group 2). The parameters analyzed were: number of implanted embryos, resorptions and corpora lutea; mating, gestation, preimplantation loss, implantation and resorption indexes (group 1); number of offspring and weaning animals (group 2). The administration of M. glomerata did not show any impairment of fertility and no significant difference in the parameters analyzed, suggesting an absence of mutagenic effect on Wistar rats.
\end{abstract}

Key words: Mikania glomerata, mutagenicity, Wistar rat

\section{INTRODUCTION}

Mikania glomerata (Sprengel - Asteraceae), popularly known in Brazil as "guaco", is a plant employed in folk medicine for treating respiratory tract diseases (Neves and Sá, 1991) and for its anti-snake venom, anti-inflammatory and analgesic activities (Ruppelt et al., 1990). Phytochemical studies have revealed the presence of several substances in M. glomerata, including kaurenoic acid, cinnamoylgrandifloric acid, stigmasterol, flavonoids and coumarin (Cabral et al., 2001; Martins et al., 2000; Oliveira et al., 1993; Vilegas et al., 1997a; Vilegas et al., 1997b) which is the main active compound from the leaves of this species. Coumarin is a well-known liver toxicant (Born et al., 2000) with reported antifertility activity in mature female rats (Ulubelen et al., 1994) whereas flavonoids have been shown to produce antiandrogenic activity and affect male fertility in dogs (Bhargava, 1989).

There are a number of agents that can have an adverse effect on the male reproductive system, for example by interfering with sexual behavior and fertility (Kimmel et al., 1995). Since $M$. glomerata contained substances with antifertility activity, this study was designed to make an assessment of the dominant lethality of $M$. glomerata in order to verify the occurrence of mutagenic effects on male Wistar rats.

\footnotetext{
${ }^{*}$ Author for correspondence
} 


\section{MATERIALS AND METHODS}

\section{Animals and housing}

Adult male Wistar rats (Rattus rattus norvegicus Berkenhout, 1769) (90 days old and weighing around $230 \mathrm{~g}$ ) were obtained from the vivarium of Universidade Federal de Juiz de Fora (UFJF), where they were born and bred. The animals were housed individually under standard laboratory conditions, with a $12 \mathrm{~h}$ light/12h dark photoperiod. They were fed on rat chow pellets and received water ad libitum. The experimental protocol was approved by the Ethical Committee of the Centro de Biologia da Reprodução (UFJF).

\section{Plant material}

M. glomerata (Sprengel) was collected in the botanical garden of the Pharmacy and Biochemistry Faculty (UFJF) and authenticated in the Herbarium Leopoldo Krieger, Department of Botany (UFJF), where a voucher specimen registered under the number CESJ 34456 is deposited. The hydroalcoholic extract was prepared using aerial parts of this plant. The aerial parts were powdered and extracted with $70 \%$ ethanol. The solvent was evaporated in a rotavapor and the residue was dissolved in distilled water.

\section{Treatment and mating procedure}

Wistar rats were randomly divided into four groups: treatment $\mathbf{T 1}$ and its control $\mathbf{C 1}$ of 12 animals each, treatment T2 and its control C2 of 11 animals each. The rats of the treatment group received, by gavage and once daily, $1 \mathrm{~mL}$ of $M$. glomerata extract at a dose level of $3.3 \mathrm{~g} / \mathrm{kg}$ of body weight, administered for 52 days. This period of time corresponded to the duration of the spermatogenic cycle of this species (Hilscher, 1964). The control group received $1 \mathrm{~mL}$ of distilled water following the same protocol as the treatment group. Each animal of groups T1 and C1 was mated with 2 untreated virgin females in estrus from the second to the eighth week of treatment (Green et al., 1985; Zenick et al., 1994) whereas each animal of groups $\mathbf{T 2}$ and $\mathbf{C 2}$ was mated with 2 untreated virgin females in estrus one week before the beginning of treatment and on the week following the end of treatment. The presence of spermatozoa in the vaginal smear indicated successful mating and was considered as day one of gestation (Gleich and Frohberg, 1977; Kato et al., 1979).
Females mated with males of groups $\mathbf{T 1}$ and $\mathbf{C 1}$ were killed by an overdose inhalation of anesthetic on the $15^{\text {th }}$ day of gestation. The following parameters were analyzed: total number of implanted embryos, number of resorptions, number of corpora lutea per pregnant female, mating index [(inseminated females/females mated) X 100], gestation index [(females with implants/inseminated females) X 100], preimplantation loss index [(corpora lutea implantations/corpora lutea) X 100], implantation index [(implantations/ corpora lutea) X 100], resorption index [(resorptions/implantations) $\mathrm{X}$ 100]. Females mated with males of groups $\mathbf{T} 2$ and C2 completed the gestational period and the following parameters were analyzed: total number of offsprings, number of males and females, total number of weaning animals, number of weaning males and females. The data were analyzed using the Fisher Exact Test and the Mann-Whitney Test $(\alpha=0.05)$ (Sokal and Rohlf, 1996).

\section{RESULTS}

The administration of $M$. glomerata hydroalcoholic extract at the dose level of $3.3 \mathrm{~g} / \mathrm{kg}$ of body weight for 52 days did not interfere with mating of the treated males. The mating, gestation, preimplantation loss, implantation and resorption indexes as well as the number of corpora lutea, implants and resorptions obtained from the females mated with treated males were not significantly different from the control values, with the exception of the mating index on the $6^{\text {th }}$ week which was significantly reduced in the treated group (Tables 1, 2 and 3). The numbers of offspring born to females mated with control and treated males one week before the beginning of treatment and on the week following the last treatment were not statistically different between the groups. The numbers of weaning females and males were also not statistically different between these groups (Table 4).

\section{DISCUSSION}

The dominant lethal test is an important method for assessment of mutagenic substances (Shively et al., 1984). In this context, mating experiments are needed to evaluate the effect of substances on 
fertility, its duration of action and whether the antifertility effect is reversible (Parveen et al., 2002). The search for an effective and reversible male antifertility agent with minimum side effects remains a challenge because although a number of compounds having antifertility effects have been isolated from higher plants most of them are metabolically toxic. In a mating experiment, the presence of implantation sites in females mated with treated males is taken as a criterion of successful insemination and the fertility test is considered to be positive. If no implants are observed the test is considered to be negative (Sakar et al., 2000). Recently, many studies have showed the antifertility effects of plant extracts in rats. For instance, the administration of Eugenia jambolana extract (Myrtaceae) reduced the number of pregnant rats and the number of implantations (Rajasekaran et al., 1988). Similar effects were observed after treatment with Abrus precatorius (Leguminosae) ethanolic extract (Sinha, 1990).

M. glomerata is a plant currently used in folk medicine for its therapeutic properties. It contains active compounds, namely flavonoids and coumarin, which have been reported to affect male dog and female rat fertility, respectively, in experiments carried out using other plant genera (Bhargava, 1989; Ulubelen et al., 1994). The antifertility effect of the substances present in the M. glomerata extract suggested a possible role of this plant as a potential agent in the field of male fertility regulation. The administration of $M$. glomerata extract for 52 consecutive days at a dose level $(3.3 \mathrm{~g} / \mathrm{kg}$ of body weight) that was 600 times higher than the human dose did not reduce the libido and, consequently, did not alter the mating behavior of the treated rats. This datum was confirmed by the presence of spermatozoa in the vaginal smear and by the number of inseminated females and with implantations, which were not reduced due to treatment. The only significant alteration was observed in the mating index of females mated with treated males on the $6^{\text {th }}$ week of treatment $(\mathbf{C 1}=87.5 \%, \mathbf{T 1}=33.3 \%)$. From $2^{\text {nd }}$ to $5^{\text {th }}$ week and on the $7^{\text {th }}$ and $8^{\text {th }}$ weeks, the mating index as well as the other parameters analyzed, including those of the $6^{\text {th }}$ week, did not differ between the control and treatment groups. The reduced mating index on the $6^{\text {th }}$ week could be considered an isolated event, which did not result in a biologically significant adverse effect.

The treatment with $M$. glomerata extract did not show any antifertility activity as evidenced by the number of implantations and resorptions observed in the females mated with treated males, which were not significantly different from the values obtained from the females mated with untreated males. Furthermore, the numbers of female and male pups born to females mated with treated males were also similar to the control values.

Table 1 - Parameters analyzed in the dominant lethality of Mikania glomerata hydroalcoholic extract in females mated with male Wistar rats submitted to chronic treatment from the $2^{\text {nd }}$ to the $4^{\text {th }}$ week.

\begin{tabular}{|c|c|c|c|c|c|c|}
\hline \multirow{3}{*}{ Parameters } & \multicolumn{6}{|c|}{ Week } \\
\hline & \multicolumn{2}{|c|}{ 2nd } & \multicolumn{2}{|c|}{ 3rd } & \multicolumn{2}{|c|}{ 4th } \\
\hline & C1 & T1 & C1 & T1 & C1 & T1 \\
\hline Females mated & 21 & 21 & 17 & 19 & 16 & 16 \\
\hline Inseminated females & 8 & 10 & 9 & 11 & 5 & 9 \\
\hline Females with implants & 8 & 7 & 8 & 11 & 5 & 9 \\
\hline Corpora lutea & 90 & 74 & 86 & 121 & 55 & 108 \\
\hline Implantations & 74 & 60 & 80 & 99 & 51 & 102 \\
\hline Resorptions & 3 & 7 & 2 & 3 & 2 & 4 \\
\hline Mating index (\%) & 38.1 & 47.6 & 52.9 & 57.9 & 31.2 & $56.2^{1}$ \\
\hline Gestation index $(\%)$ & 100 & 70 & 88.9 & 100 & 100 & $100^{2}$ \\
\hline Preimplantation loss index (\%) & 17.8 & 18.9 & 7 & 18.2 & 7.3 & $5.5^{3}$ \\
\hline Implantation index $(\%)$ & 82.2 & 81.1 & 93 & 81.8 & 92.7 & $94.4^{4}$ \\
\hline Resorption index $(\%)$ & 4 & 11.7 & 2.5 & 3 & 3.9 & $3.9^{5}$ \\
\hline
\end{tabular}

$C 1=$ control, $T 1=$ treatment. $1-$ mating index $=($ inseminated females/females mated $) X 100.2-$ gestation index $=($ females with implants/inseminated females) X 100. 3 - preimplantation loss index $=($ corpora lutea - implants/corpora lutea $) X 100.4-$ implantation index $=($ implants/corpora lutea $) X 100.5-$ resorption index $=($ resorptions/implants $) X 100$. 
Table 2 - Parameters analyzed in the dominant lethality of Mikania glomerata hydroalcoholic extract in females mated with male Wistar rats submitted to chronic treatment from the $5^{\text {th }}$ to the $8^{\text {th }}$ week.

\begin{tabular}{|c|c|c|c|c|c|c|c|c|}
\hline \multirow{3}{*}{ Parameters } & \multicolumn{8}{|c|}{ Week } \\
\hline & \multicolumn{2}{|c|}{ 5th } & \multicolumn{2}{|c|}{ 6th } & \multicolumn{2}{|c|}{ 7th } & \multicolumn{2}{|c|}{ 8th } \\
\hline & C1 & T1 & C1 & T1 & C1 & T1 & C1 & T1 \\
\hline Females mated & 10 & 12 & 8 & 12 & 12 & 12 & 12 & 12 \\
\hline Inseminated females & 7 & 4 & 7 & 7 & 5 & 2 & 7 & 9 \\
\hline Females with implants & 7 & 3 & 7 & 4 & 5 & 2 & 6 & 8 \\
\hline Corpora lutea & 74 & 36 & 85 & 43 & 55 & 23 & 59 & 82 \\
\hline Implantations & 73 & 33 & 83 & 41 & 50 & 22 & 55 & 77 \\
\hline Resorptions & 4 & 1 & 5 & 2 & 2 & 0 & 3 & 4 \\
\hline Mating index $(\%)$ & 70 & 33.3 & 87.5 & $33.3^{*}$ & 41.7 & 16.7 & 58.3 & $75^{1}$ \\
\hline Gestation index $(\%)$ & 100 & 75 & 100 & 100 & 100 & 100 & 85.7 & $88.9^{2}$ \\
\hline Preimplantation loss index $(\%)$ & 1.3 & 8.3 & 2.3 & 4.6 & 9.1 & 4.3 & 6.8 & $6.1^{3}$ \\
\hline Implantation index $(\%)$ & 98.6 & 91.7 & 97.7 & 95.3 & 90.9 & 95.7 & 93.2 & $93.9^{4}$ \\
\hline Resorption index $(\%)$ & 5.5 & 3 & 6 & 4.9 & 4 & 0 & 5.4 & $5.2^{5}$ \\
\hline
\end{tabular}

$\mathrm{C} 1=$ control, $\mathrm{T} 1=$ treatment. $1-$ mating index $=($ inseminated females/females mated $) \mathrm{X} \mathrm{100.2- \text {gestationindex } = ( \text { females }}$ with implants/inseminated females) X 100. 3 - preimplantation loss index $=$ (corpora lutea-implants/corpora lutea) $\mathrm{X} 100.4-$ implantation index $=($ implants/corpora lutea $) X 100.5-$ resorption index $=($ resorptions/implants $) X 100 . * p=0,0281$.

Table 3 - Total values obtained during the seven weeks of mating of control and Mikania glomerata-treated animals.

\begin{tabular}{lcc}
\hline \multicolumn{1}{c}{ Parameters } & Control & Treated \\
\hline Females mated & 96 & 104 \\
Inseminated females & 48 & 49 \\
Females with implants & 46 & 44 \\
Corpora lutea & 504 & 487 \\
Implants & 466 & 434 \\
Resorptions & 21 & 21 \\
\hline
\end{tabular}

Table 4 - Males and females born and weaned of females mated with control and treated males one week before the beginning of treatment and on the week following the last treatment with Mikania glomerata hydroalcoholic extract.

\begin{tabular}{lcccc}
\hline \multirow{2}{*}{ Parameters } & \multicolumn{2}{c}{ Before } & \multicolumn{2}{c}{ After } \\
\cline { 2 - 5 } & Control & Treated & Control & Treated \\
\hline Born males & 43 & 32 & 66 & 53 \\
Born females & 50 & 46 & 55 & 45 \\
Total & 93 & 78 & 121 & 98 \\
Weaning males & 42 & 32 & 64 & 52 \\
Weaning females & 49 & 45 & 55 & 45 \\
Total & 91 & 77 & 119 & 97 \\
\hline
\end{tabular}

In rats, the number of embryonic deaths can be measured by the resorption index. This correlates the total number of implants with live embryos, dead embryos, embryo remains or just the residue of an implantation. In this work, the resorption index, a reliable measure of dominant lethal mutations (Aravindakshan et al., 1985), was not significantly altered in females mated with treated males. In conclusion, despite the presence of potential mutagenic substances in its aerial parts, the $M$. glomerata extract was not genotoxic to the germinal cells of Wistar rats at the dose level used during treatment. It did not cause the death of embryos nor did it affect their development and fixation on the maternal uterus. 


\section{ACKNOWLEDGEMENTS}

The authors are grateful to Dr. Penny Hawkins for reviewing the English version of the manuscript and to Paulo Sérgio do Carmo, Evelise Rocha de Souza and José Wilson Pereira for technical support.

\section{RESUMO}

Mikania glomerata é uma planta utilizada na medicina popular, cujas folhas possuem flavonóides e cumarina. Essas substâncias, segundo a literatura, interferem na fertilidade de cães e ratas, respectivamente. $\mathrm{O}$ presente trabalho faz um estudo do teste do letal dominante com $M$. glomerata em ratos Wistar. Animals adultos foram tratados com $1 \mathrm{~mL}$ de extrato hidroalcoólico de $M$. glomerata na dose de $3.3 \mathrm{~g} / \mathrm{kg}$ de peso corporal durante 52 dias. Os animais foram acasalados com fêmeas não tratadas por sete semanas (grupo 1) ou uma semana antes do início do tratamento e na semana seguinte ao término do mesmo (grupo 2). As variáveis analisadas foram: números de embriões implantados, reabsorções e corpos lúteos, índices de acasalamento, gestação, perda pré-implantação, implantação e reabsorção (grupo 1); número de filhotes nascidos e de animais desmamados (grupo 2). A administração de $\mathbf{M}$. glomerata não interferiu com a fertilidade dos animais e não foram observadas alterações significativas das variáveis analisadas, o que sugere a ausência de efeito mutagênico em ratos Wistar por parte dessa planta.

\section{REFERENCES}

Aravindakshan, M.; Chauhan, P. S. and Sundaram, K. (1985), Studies on germinal effects of quercetin, a naturally occurring flavonoid. Mutation Res., 144, 99-106.

Bhargava, S. K. (1989), Antiandrogenic effects of a flavonoid rich fraction of Vitex negundo seeds: a histological and biochemical study in dogs. $J$. Ethnopharmacol., 27, 327-339.

Born, S. L.; Caudill, D.; Smith, B. J. and LehmanMcKeeman, L. D. (2000), In vitro kinetics of coumarin 3,4-epoxidation: application to species differences in toxicity and carcinogenicity. Toxicol. Sci., 58, 23-31.
Cabral, L. M.; Dos Santos, T. C. and Alhaique, F. (2001), Development of a profitable procedure for the extraction of 2-H-1-benzopyran-2-one (coumarin) from Mikania glomerata. Drug Develop. Indust. Pharm., 27,103-106.

Gleich, J. and Frohberg, H. (1977), General teratological techniques. In: Neubert, D. et al. (Ed.). Methods in prenatal toxicology. Evaluation of embryotoxic effects in experimental animal. Massachusetts: PSG Publishing. pp. 94-102.

Green, S.; Auletta, A.; Fabricant, J.; Kapp, R.; Manandhar, M.; Sheu, C.; Springer, J. and Whitfield, B. (1985), Current status of assays in genetic toxicology the dominant lethal test. Mutation Res., 54, 49-67.

Hilscher, W. (1964), Beitrage zur orthologre und palhologie des "spermatogoniogenes" der ratte. Beitr.Pathol. Anat., 130, 69-132.

Kato, H.; Morishige, W. K. and Rotchild, I. (1979), A quantitative relationship between the experimentally determined number of conceptuses and corpus luteum activity in pregnant rat. Endocrinol., 105, 846-850.

Kimmel, G. L.; Clegg, E. and Crisp, T. M. (1995), Reproductive toxicity testing: A risk assessment perspective. In: Witorsch, R. J. (Ed.). Reproductive Toxicology. New York: Raven Press. pp. 75-98.

Martins, E. R.; Castro, D. M.; Castellani, D. C. and Dias, J. E. (2000), Plantas Medicinais. Viçosa: UFV. pp. 132-134.

Neves, L. J. and Sá, M. F. A. (1991), Contribuição ao estudo das plantas medicinais Mikania glomerata Spreng. Rev. Bras. Farm., 72, 42-47.

Oliveira, F.; Saito, M. L. and Garcia, L. O. (1993), Caracterização cromatográfica em camada delgada do extrato fluído de guaco - Mikania glomerata Sprengel. LECTA-USF., 11, 43-56.

Parveen, S.; Das, S.; Kundra, C. P. and Pereira, B. M. J. (2002), A comprehensive evaluation of the reproductive toxicity of Quassia amara in male rats. Reprod. Toxicol., 17, 19-23.

Rajasekaran, M.; Bapna, J. S.; Lakshmanan, S., Ramachandran Nair, A. G.; Veliath, A. J. and Panchanadam, M. (1988). Antifertility effect in male rats of oleanolic acid, a triterpene from Eugenia jambolana flowers. J. Ethnopharmacol., 24, 115-121.

Ruppelt, B. M.; Pereira, E. F. R.; Gonçalves, L. C. and Pereira, N. A. (1990), Abordagem farmacológica de plantas recomendadas na medicina folclórica como antiofídicas. I - Atividades analgésica e antinflamatória, Rev. Bras. Farm., 71, 54-56.

Sarkar, M.; Gangopadhyay, P.; Basak, B.; Chakrabarty, K.; Banerji, J.; Adhikary, P. and Chatterjee, A. (2000), The reversible antifertility effect of Piper betle Linn. on Swiss albino male mice. Contraception, 62, 271-274.

Shively, C. A.; White, D. M.; Blauch, J. L. and Tarka Jr., S. M. (1984), Dominat lethal testing of theobromine in rats. Toxicol. Letters, 20, 325-329. 
Sinha, R. (1990), Post-testicular antifertililty effects of Abrus precatorius seed extract in albino rats. $J$. Ethnopharmacol., 28, 173-181.

Sokal, R. R.; Rohlf, F. J. and Biometry, F. (1996), The principles and practice of statistics in biological research. New York: WH Freeman and Co. pp. 850.

Ulubelen, A.; Ertugrul, L.; Birman, H.; Yigit, R.; Erseven, G. and Olgac, V. (1994), Antifertility effects of some coumarins isolated from Ruta chalepensis and $R$. chalepensis var. latifolia in rodents. Phytother. Res., 8, 233-236.

Vilegas, J. H. Y.; Marchi, E. and Lanças, F. M. (1997a), Extraction of low-polarity compounds (with emphasis on coumarin and kaurenoic acid) from Mikania glomerata ("guaco") leaves. Phytochem. Anal., 8, 266-270.

Vilegas, J. H. Y.; Marchi, E. and Lanças, F. M. (1997b), Determination of coumarin and kaurenoic acid in Mikania glomerata ("guaco") leaves by high resolution gas chromatography. Phytochem. Anal., 8, 74-77.

Zenick, H.; Clegg, E. D.; Perreault, S. D.; Klinefelter, G. R. and Gray, L. E. (1994), Assessment of male reproductive toxicity: a risk assessment approach. In: Hayes, A.W. (Ed.). Principles and Methods of Toxicology. New York: Raven. pp. 937-988. 